dates are sifterl. The fact that outside assessors, many of them academics, help in the selection of candirlates gives the system objectivity. The awarders seem also to have been fortunate in the people chosen so far, who have becn acknowledged by their colleagues as outstanding research workers. For the civil service one important consequence is that the scientific establishments are able to compete on more even terms with the universities for the services of bright people.

\section{Ritual and Behaviour}

IVHeN spiders are given lysergic acid they construct webs of more than usual regularity; they become, like man in a similar situation, withdrawn from external stimuli so that their perceptive awareness is reduced, and they cease to adjust their webs to the irregularities of the surroundings. 'This example is used by Sir Julian Huxley in his introduction to $A$ Discussion on Ritualization of Behaviour in Animals and Man (Phil. Trans. Roy. Soc., B, 251, 247; 1966) to illustrate the importance of perecption in ritualized behaviour. Psychedelic substances, as well as schizophrenia, distort perception to the extent that contact with external objects is jevented.

Ritualization can he described broadly as the adaptive formalization of behaviour through the influence of natural sclection. It seems to have occurred in animals as a means of improving signalling to other inclividuals; to serve as a more efficient stimulator of more efficient patterns of action in others; to reduce intra-specific damage, and to serve as sexual or social bonding mechanisms. Sexual display and threat activities act as signals to other animals, and stimulate a particular pattern of reactions. Threat can reduce lamage; in some lizards threat is expressed by sizeexaggeration and fighting never occurs. 'The antlers of deer are so constructed that fights are rarely fatal, and are so large that combatants are often deterred. Social bonding rituals include grooming, particularly in nonhuman primates. In fishes, too, the removal of harmful growths from one species by another benefits both. In many mammals, play is a socializing activity, for example in young monkeys, and in lions where both adults and young are involved. During the evolution of vertebrates, ritualization has tended more towards the maintenance of efficient bonding and ceremonies have become more claborate, with individual learning plaving an increasingly important role. Particularly in the primates, ritualized behaviour resembles to some extent that of humans.

\section{Graduates in Industry \\ by our Special Correspondent}

A FREQUENT criticism of British industry is that it fails to attract graduates in science and technology, or to make good use of those it does attract. The Swann and Willis Jackson Reports (Nature, 212, 227; 1966) on scientific manpower implied that the universities are to blame for absorbing too many of their own graduates instead of dispatching them into the world with a determination to use their talents in a dircctly productive way. One reason is certainly the rapid expansion of the universities, which has enabled them to find places for increasing numbers of graduates before producing a comparable increase in their own output, but another may be that industry is unable to present itself as an attractive alternative. Nature has recently been talking to twelve science graduates (all men) from the universities of Oxford and London with one or two years experience of industry, and asking them why they joined, and whether they regret their decision. The names were supplied by the two university appointments boards, and the companies included breweries, computer and chemical companies, and companies in the motor industry. The only proviso is that most of the companies were large.

Very few of the group questioned admitted to any regrets. "Industry is far more interesting from the inside than it looks from the outside" was a typical comment. An Oxford chemist compared the flexibility of industry with the rigidity and absence of a defined carcer structure in university life--"In a big company there is bound to be a job one enjoys doing", he said. None of them expressed any desire to return to academic life, although opinions of universities varied. One graduate, working for a computer company, said that he thought academic life too dedicated, but another, an Oxford graduate also in a computer firm, remarked that "university centres around fun, industry around work". In general they neither praised nor criticized university life, and seemed not to have felt the conflicting claims of industry and the universities. For some, of course, the university option was olosed because their degrees were insufficiently good Academic life, often seen as the prize awarded for a first class degree, is unlikely to be considered by those who feel, rightly or wrongly, that they are going to get a third. Industry, which cares least what degrees its recruits have, is likely to be the beneficiary; this may explain why so few seemed to have felt a conflict. Discouraged early in their university careers, people are likcly to sce their degree courses as a way of qualifying themselves for something else as soon as possible.

Most of those questioned believe that scientists have as good a chance of reaching the top in industry as anyone else. The widely canvassed claim that British industry discriminates against scientists found no support. While this is unsurprising from a group of industrial scientists, there is some evidence that their optimism is justified. A study carried out in northwest England by D. G. Clark of the University of Manchester Institute of Science and Technology ${ }^{1}$ shows that 80 per cent of all graduates in managerial positions are scientists. There is, in fact, a broad correspondence between the proportions of graduates from different disciplines going into industry and the proportion in managerial positions, since an earlier report by P.E.P. (ref. 2) showed that at the beginning of the fifties about 78 per cent of the graduates entering industry were scientists or technologists. A more legitimate criticism might be that industry fails to employ enough graduates generally (only 35 per cent of the managers in the Manchester study were graduates). It may be that scientists are still under-represented in the boardrooms, either because the wave of scientific managers has not reached this level yetthere are more scientists among younger managers than among older-or beeause of the complicating factor of background. Public schools, for instance, produce fewer scientists but more managers. 